\title{
New Limonoids from Dictyoloma vandellianum and Sohnreyia excelsa: Chemosystematic Considerations
}

\author{
Claudenice F. P. Sartor, ${ }^{a}$ Maria da Paz Lima, ${ }^{a, b}$ Maria Fátima G. F. da Silva, ${ }^{(0 *, a}$ \\ João B. Fernandes, ${ }^{a}$ Moacir R. Forim ${ }^{a}$ and José R. Pirani ${ }^{c}$ \\ ${ }^{a}$ Departamento de Química, Universidade Federal de São Carlos, \\ CP 676, 13565-905 São Carlos-SP, Brazil
}

${ }^{b}$ Coordenação de Pesquisas em Produtos Naturais, Instituto Nacional de Pesquisas da Amazônia, CP 478, 69011-970 Manaus-AM, Brazil

'Instituto de Biociências, Departamento de Botânica, Universidade de São Paulo, 05508-900 São Paulo-SP, Brazil

\begin{abstract}
Molecular phylogenetic studies separated and united a group of genera that constituted the Spathelia-Ptaeroxylon clade, in which Dictyoloma and Sohnreyia have been included. Our taxonomic interest in the Dictyoloma vandellianum and Sohnreyia excelsa stimulated an investigation of both species searching for limonoids. Leaves from $D$. vandellianum afforded the new limonoid 1,2-dihydro-1 $\alpha$-hydroxy-8,30-epoxy-cneorin $\mathrm{R}$, and heartwood yielded the new rearranged limonoid dictyolomin. Leaves from $S$. excelsa afforded the new protolimonoid $3 \beta$-angeloyloxy-7 $\alpha, 24,25$-trihydroxy-21,23-oxide-14,18-cycloapotirucall-21-methoxycetal and the new cycloheptanyl ring $\mathrm{C}$ limonoid with carbonate substituent and named as sohnreyolide. The new limonoids from Sohnreyia and Dictyoloma show similarities with those from Rutaceae and Meliaceae, providing support for moving Spathelia-Ptaeroxylon clade near to these associated large families.
\end{abstract}

Keywords: Spathelia-Ptaeroxylon clade, Dictyoloma, Sohnreyia, Rutaceae, limonoids

\section{Introduction}

Molecular phylogenetic studies separated and united a group of genera that constituted the Spathelia-Ptaeroxylon clade, which has been included in Rutaceae. ${ }^{1}$ This clade comprises seven genera: Bottegoa, Cedrelopsis, Cneorum, Dictyoloma, Spathelia, Harrisonia and Ptaeroxylon. However, most of these genera have been associated with other families. Spathelia L. and Dictyoloma Juss. have been assigned to both Simaroubaceae and Rutaceae. ${ }^{2,3}$ The other five genera have been traditionally placed in the Simaroubaceae (Harrisonia), Meliaceae (Ptaeroxylon, Cedrelopsis), Sapindaceae (Bottegoa), Cneoraceae (Cneorum) and Ptaeroxylaceae (Ptaeroxylon, Cedrelopsis, Bottegoa). ${ }^{4-8}$

Relevant data are available on the anatomical characters and five plastid deoxyribonucleic acid (DNA) regions, which show that with the exception of Spathelia, all other genera are monophyletic. ${ }^{1}$ These data also show

*e-mail: dmfs@ufscar.br that this clade is well placed in Rutaceae, and they also suggest uniting them in a subfamily, Spathelioideae. The results led to a new circumscription of Spathelia species, and Caribbean species were regarded as Spathelia, S. bahamensis, S. brittonii, S. coccinea, S. cubensis, S. glabrescens, S. sorbifolia, S. splendens, S. vernicosa and S. wrightii. The South American species of Spathelia were distinct from all other Caribbean; thereby they were separated into a Sohnreyia genus.

Spathelia excelsa from Brazil and S. ulei from Venezuela were originally described as Sohnreyia excelsa Krause (1914) $)^{9}$ and Diomma ulei Engl. ex Harms (1931), ${ }^{10}$ respectively. Due to the law of priority in botanical nomenclature Sohnreyia has priority over Diomma. Therefore, Sohnreyia comprises four species: S. excelsa, S. giraldiana (Colombia), S. terminalioides (Peru) and S. ulei. ${ }^{1}$

Dictyoloma contains one species, D. vandellianum Adr. Juss. (syn. D. incanescens DC) which occurs in Brazil, and according to above revision includes $D$. peruvianum from Peru. ${ }^{3,11}$ 
A simple indole (1) occurs in Dictyoloma, but it is very rare in Rutaceae. Dictyoloma, Spathelia and Sohnreyia are characterized by 2-quinolinone (2-8), 2-alkyl-4(1H)-quinolone (9-21) alkaloids, simple and prenylated chromones $(\mathbf{2 2 - 4 2})$, protolimonoids $(\mathbf{4 3}, \mathbf{4 4})$ and limonoids (45-54) (Figures 1-3).

Dictyoloma vandellianum is known to contain indole (1), 2-quinolinone $(\mathbf{3}, \mathbf{4}, \mathbf{6}, \mathbf{7}), 2$-alkyl-4(1H)-quinolone (12-15, 20) alkaloids, prenylated chromones $(\mathbf{2 5 - 2 7}, \mathbf{3 1 - 3 3}, \mathbf{4 2})$ and limonoids $(\mathbf{4 5}, \mathbf{4 7}, \mathbf{4 9}, \mathbf{5 1}, \mathbf{5 2}) .{ }^{12-17}$ The only known metabolites from $D$. vandellianum ex $D$. peruvianum are two 2-alkyl-4(1H)-quinolone alkaloids (19 and 21). ${ }^{18}$

The known compounds from Spathelia and Sohnreyia are typical of D. vandellianum. Little is known about the chemistry of the Caribbean species, data are available for Spathelia glabrescens, S. sorbifolia and S. wrightii. In S. glabrescens were found prenylated chromones $(\mathbf{2 3}, \mathbf{2 5}$, $\mathbf{2 7}, \mathbf{4 2}$ ) and the unusual squalene derivatives glabrescol (55) and epoxy tri-tetrahydrofuran (THF) diol (56) (Figure 3). ${ }^{19-21}$ Ethereal squalene derivatives were also isolated from Quassia multiflora, ${ }^{22}$ confirming the chemical affinity of Spathelia with Simaroubaceae. Chemical data on $S$. wrightii are very scarce; only one prenylated chromone (35) was found. ${ }^{23}$ S. sorbifolia contains 2-quinolinone (3, 5), prenylated chromones (23-25, 27-31, $33,34,37,39-42)$ and limonoids $(46,48,50){ }^{24-28}$

Sohnreyia excelsa has been the more widely investigated (however, it appears in all original literature as Spathelia excelsa), and it produces 2-quinolinone (2-4, 8), 2-alkyl-4(1H)-quinolone (9-11, 13, 16-18) alkaloids, prenylated chromones $(\mathbf{2 2}, \mathbf{3 6}, \mathbf{3 8})$, protolimonoids $(\mathbf{4 3}$, $\mathbf{4 4 )}$ and limonoids $(\mathbf{4 5}, \mathbf{5 1}, \mathbf{5 3}, \mathbf{5 4}){ }^{29-32}$

As part of our continuous investigation into the chemical composition of Brazilian S. excelsa and $D$. vandellianum, we reported the isolation of thirteen 2-alkyl-4(1H)-quinolone alkaloids from leaves of both species. ${ }^{16,29}$ The isolation of these interesting new alkaloids combined with our taxonomic interest in the Spathelia-Ptaeroxylon clade stimulated an investigation of other organs of $D$. vandellianum. The phytochemical studies of $S$. excelsa leaves were undertaken in our laboratory, and we used the same experimental procedures applied in the present work and in others similar, and these allowed to isolate coumarins and limonoids. In order to look<smiles>COc1ccc2c(c1)c(CCN(C)C)cn2C</smiles>

1<smiles>[R]c1ccc2c(OC)cc(=O)n(C)c2c1[R]</smiles>

2: $\mathrm{R}=\mathrm{OMe}, \mathrm{R}_{1}=\mathrm{H}$

3: $\mathrm{R}=\mathrm{R}_{1}=\mathrm{OMe}$

4: $\mathrm{R}-\mathrm{OCH}_{2} \mathrm{O}-\mathrm{R} 1$<smiles>[R2]c1ccc2c3c(c(=O)n([R])c2c1[R])C=CC(C)(C)O3</smiles>

5: $\mathrm{R}=\mathrm{Me}, \mathrm{R}_{1}=\mathrm{R}_{2}=\mathrm{H}$

6: $\mathrm{R}=\mathrm{H}, \mathrm{R}_{1}=\mathrm{OMe}, \mathrm{R}_{2}=\mathrm{H}$

7: $\mathrm{R}=\mathrm{Me}, \mathrm{R}_{1}=\mathrm{OMe}, \mathrm{R}_{2}=\mathrm{H}$

8: $R=H, R_{1}=R_{2}=O M e$<smiles>[R]c1cc2[nH]c(CNC(C)(C)O)c([R])c(=O)c2cc1[R2]</smiles>

9: $\mathrm{n}=1, \mathrm{R}=\mathrm{H}, \mathrm{R}_{1}=\mathrm{H}, \mathrm{R}_{2}=\mathrm{OH}$

$10: n=1, R=H, R_{1}=O H, R_{2}=H$

11: $n=9, R=O M e, R_{1}=R_{2}=H$

12: $n=10, R=R_{1}=R_{2}=H$

13: $n=10, R=O M e, R_{1}=R_{2}=H$<smiles>[R]c1c(CNC(O)C(C)C)[nH]c2ccccc2c1=O</smiles>

14: $\mathrm{R}=\mathrm{H}$

15: $\mathrm{R}=\mathrm{OMe}$<smiles>[R]c1c(CNC(C)(C)O)[nH]c2ccccc2c1=O</smiles>

16: $\mathrm{R}=\mathrm{OMe}$<smiles>[R]c1c(CNC(C)=O)[nH]c2ccccc2c1=O</smiles>

17: $\mathrm{R}=\mathrm{OMe}$<smiles>[R]c1c(CNC(C)O)[nH]c2ccccc2c1=O</smiles>

18: $\mathrm{R}=\mathrm{OMe}$<smiles>[R]c1ccc2c(c1)c(=O)cc1n2CC(CC/C=C/CC)CC1</smiles>

19: $\mathrm{R}=\mathrm{H}$ 20: $\mathrm{R}=\mathrm{OMe}$

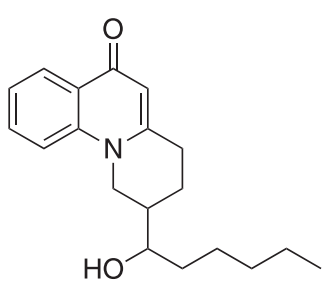

21

Figure 1. Indole (1), 2-quinolinone (2-8) and 2-alkyl-4(1H)-quinolone (9-21) alkaloids from Spathelia-Ptaeroxylon clade. 
<smiles>Cc1cc(=O)c2c(O)c(C(O)OC3C(O)CC4(O)C(O)CC3C4O)c(O)cc2o1</smiles>

22<smiles>Cc1cc(=O)c2c(O)cc3c(c2o1)C=CC(C)(C)O3</smiles>

23: $\mathrm{R}=\mathrm{H}$

24: $\mathrm{R}=\mathrm{Me}$<smiles>Cc1cc(=O)c2c(O)c3c(c(CCC(C)C)c2o1)OC(C)(C)C=C3</smiles>

31: $\mathrm{R}=\mathrm{H}, 2^{\prime}, 3^{\prime}$-dehydro

32: $\mathrm{R}=\mathrm{Me}, 2^{\prime}, 3^{\prime}$-dehydro

33: $\mathrm{R}=\mathrm{Me}, 3^{\prime}-\mathrm{OH}, 1^{\prime}, 2^{\prime}$-dehydro

34: $\mathrm{R}=\mathrm{H}, 1^{\prime}=\mathrm{O}, 2^{\prime}, 3^{\prime}$-dehydro

35: $\mathrm{R}=\mathrm{Me}, 1^{\prime}=0,2^{\prime}, 3^{\prime}$-dehydro

36: $\mathrm{R}=\mathrm{H}, 2^{\prime}, 3^{\prime}$-epoxy

37: $\mathrm{R}=\mathrm{H}, 2^{\prime}, 3^{\prime}-\mathrm{diOH}$

38: $\mathrm{R}=\mathrm{Me}, 2^{\prime}, 3^{\prime}-\mathrm{diOH}$

39: $\mathrm{R}=\mathrm{H}, 1^{\prime}, 2^{\prime}, 3^{\prime}$-triOH

40<smiles>[CH]C(S)CC[C]c1c2c(c3oc(C)cc(=O)c3c1O)C=CC(C)(C)O2</smiles>

25: $\mathrm{R}=\mathrm{H}, 2^{\prime}, 3^{\prime}$-dehydro

26: $\mathrm{R}=\mathrm{Me}, 2^{\prime}, 3^{\prime}$-dehydro

27: $\mathrm{R}=\mathrm{H}, 3^{\prime}-\mathrm{OH}, 1^{\prime}, 2^{\prime}$-dehydro

28: $\mathrm{R}=\mathrm{Me}, 3^{\prime}-\mathrm{OH}, 1^{\prime}, 2^{\prime}$-dehydro

29: $R=H, 1^{\prime}, 2^{\prime}, 3^{\prime}, 4^{\prime}$-dehydro<smiles>COc1cc2oc(C)cc(=O)c2c2c1C=CC(C)(C)O2</smiles><smiles>COc1c2c(c3c(=O)cc(C)oc3c1/C=C/C(C)(C)O)OC(C)(C)C=C2</smiles><smiles>Cc1cc(=O)c2c3c(c4c(c2o1)C=CC(C)(C)O4)C=CC(C)(C)O3</smiles>

Figure 2. Simple and prenylated chromones (22-42) from Spathelia-Ptaeroxylon clade.

for these compounds we have now undertaken a further investigation of $S$. excelsa leaves. Now we report in this work four new limonoids 57-60 (Figure 4).

Limonoids are found in three families, Rutaceae, Meliaceae and Cneoraceae, which help to confirm the close ties between them. However, there are fairly consistent differences between the limonoids of Rutaceae and those of the Meliaceae and Cneoraceae. ${ }^{33}$ In a recent paper ${ }^{34}$ on limonoids the authors highlights the advances of this class regarding a wide spectrum of biological properties mainly as insecticidal activities. The tetracyclic ring system of limonoid suffers degradation by several routes, by opening of rings $\mathrm{A}, \mathrm{B}, \mathrm{C}$ and $\mathrm{D}$, as the new rearranged limonoids obtained in the present work. ${ }^{33}$ Calodendrolide and fraxinellone compounds appear to arise biogenetically by extensive degradation of the limonoid system. Both co-occur with limonoids and represent metabolic fragments containing only the limonoid C- and D-rings. The relative and absolute configurations in both are consistent with their limonoid origin. ${ }^{35}$ Fraxinellone containing only $\mathrm{C}$ - and D-rings shows insecticidal activities. ${ }^{36}$

\section{Experimental}

\section{General}

Nuclear magnetic resonance (NMR), heteronuclear single quantum correlation (HSQC), heteronuclear multiple bond correlation (HMBC) and nuclear overhauser effect spectroscopy (NOESY) spectra were acquired on a Bruker DRX 400 spectrometer, with tetramethylsilane (TMS) as internal standard; electrospray ionization mass spectra (ESI-MS) were obtained at low resolution on a triple quadrupole Micromass Quattro LC instrument, equipped with a "'Z-spray" ion source; high resolution mass spectra (HRMS) were obtained on a Fisons VG Autospec; infrared (IR) spectra were obtained with a Bomem Fourier transform (FT) / IR spectrometer; ultraviolet (UV) spectra were obtained with a PerkinElmer model 8452A spectrophotometer.

\section{Plant material}

Dictyoloma vandellianum was collected in Campinas, SP, Brazil, and identified by J. R. Pirani (Universidade de São Paulo (USP)). A voucher (SPF 81-317) is deposited in the Herbarium of Instituto de Biociências, USP, São Paulo. S. excelsa was collected in the Adolpho Ducke Forest Reserve, Manaus, AM, Brazil, and identified by J. R. Pirani. A voucher specimen (4227) is deposited in the Herbarium of the Instituto Nacional de Pesquisa da Amazônia (INPA), Manaus, AM, Brazil.

Isolation of compounds

Ground leaves $(300 \mathrm{~g})$ and heartwood $(1 \mathrm{~kg})$ of D. vandellianum were extracted with hexane, then $\mathrm{CH}_{2} \mathrm{Cl}_{2}$ 


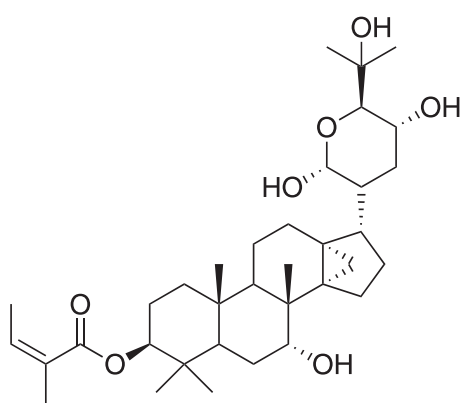

43

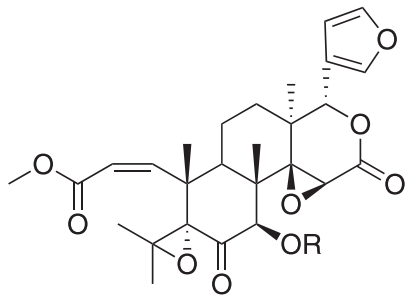

45: $\mathrm{R}=\mathrm{H}$

46: $R=A C$

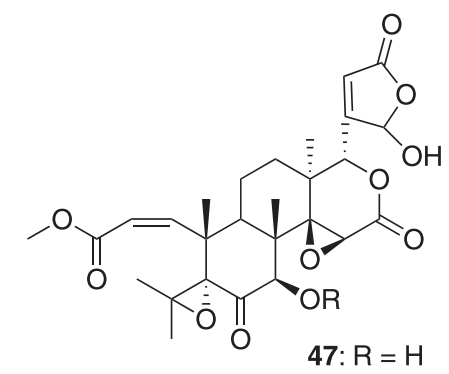

48: $R=A c$

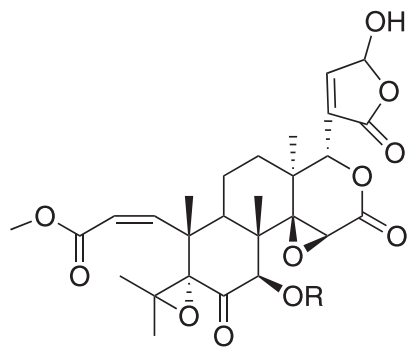

49: $\mathrm{R}=\mathrm{H}$

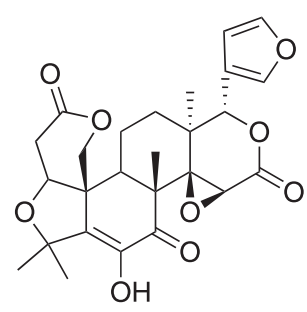

51

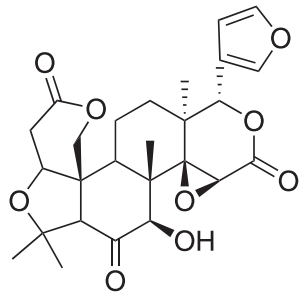

52

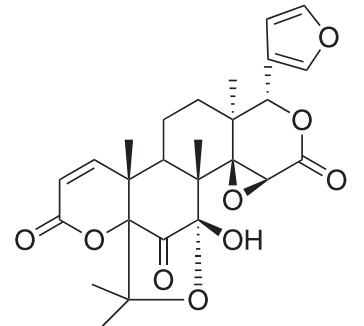

53

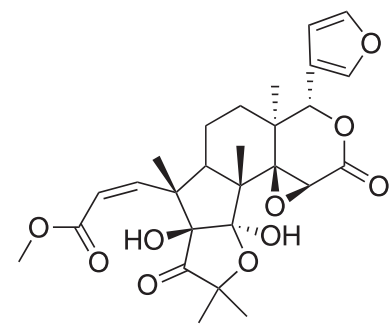

54

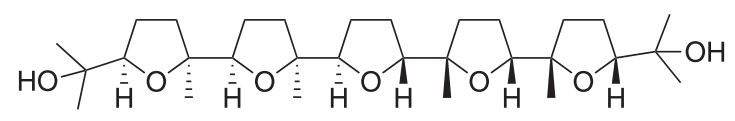

55

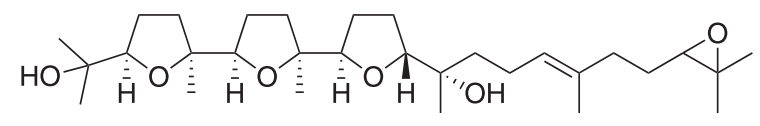

56

Figure 3. Protolimonoids $(\mathbf{4 3}, \mathbf{4 4})$, limonoids $(\mathbf{4 5 - 5 4})$ and the unusual squalene derivatives $(\mathbf{5 5}, \mathbf{5 6})$ from Spathelia-Ptaeroxylon clade.

and finally with $\mathrm{MeOH}$. The concentrated $\mathrm{CH}_{2} \mathrm{Cl}_{2}$ extract from leaves was subjected to column chromatography (CC) over silica gel. Elution with hexane, followed by a $\mathrm{CH}_{2} \mathrm{Cl}_{2}$-EtOAc- $\mathrm{Me}_{2} \mathrm{CO}-\mathrm{MeOH}$ gradient yielded eight fractions (frs). Fraction (Fr.) 2 was chromatographed on cellulose, eluting with a hexane- $\mathrm{CH}_{2} \mathrm{Cl}_{2}$-EtOAc gradient to afford $6(3 \mathrm{mg})$ and additional frs. Fr. 2.1 was applied to Sephadex LH-20 (EtOAc), then on silica gel (hexane$\mathrm{CH}_{2} \mathrm{Cl}_{2}$-EtOAc gradient) to give $\beta$-sitosterol $(13 \mathrm{mg})$. Fr. 6 was chromatographed on Sephadex LH-20, eluting with $\mathrm{MeOH}$ affording a Fr. containing 58. It was then purified by preparative thin-layer chromatography (TLC) (silica gel; $\mathrm{CHCl}_{3}-\mathrm{MeOH}, 95: 5$ ) to give $24 \mathrm{mg}$ of $\mathbf{5 8}$. The concentrated $\mathrm{MeOH}$ extract from leaves was subjected to $\mathrm{CC}$ over silica gel. Elution with hexane, followed by a $\mathrm{CH}_{2} \mathrm{Cl}_{2}$-EtOAc- $\mathrm{Me}_{2} \mathrm{CO}-\mathrm{MeOH}$ gradient yielded four frs. Fr. 2 was applied to Sephadex LH-20, eluting with $\mathrm{MeOH}$ afforded a Fr. containing 45. It was then purified by preparative TLC (silica gel; hexane-EtOAc, 20:80) to give $14 \mathrm{mg}$ of $\mathbf{4 5}$. The concentrated $\mathrm{CH}_{2} \mathrm{Cl}_{2}$ extract from heartwood was subjected to $\mathrm{CC}$ over silica gel. Elution with hexane, followed by a $\mathrm{CH}_{2} \mathrm{Cl}_{2}-\mathrm{EtOAc}-\mathrm{Me}_{2} \mathrm{CO}-\mathrm{MeOH}$ gradient yielded sixteen frs. Fr. 7 was applied three times to Sephadex $\mathrm{LH}-20\left(\mathrm{CHCl}_{3}-\mathrm{MeOH}, 1: 1 ; \mathrm{MeOH}\right.$; 


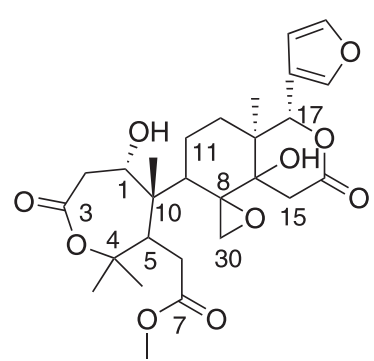

57

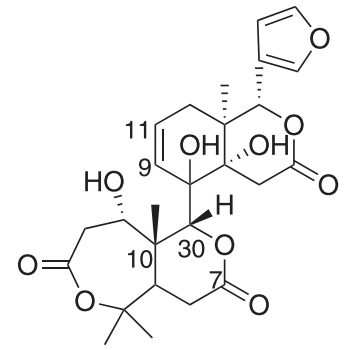

58

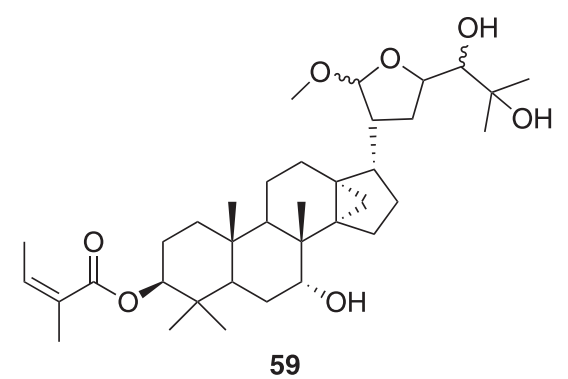

59

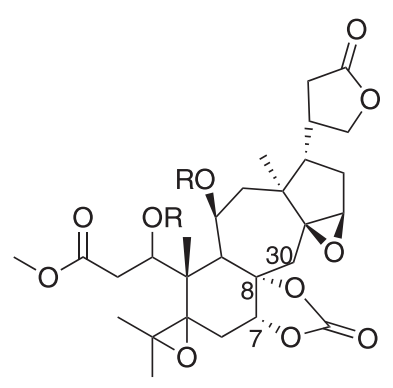

60: $R=A c$

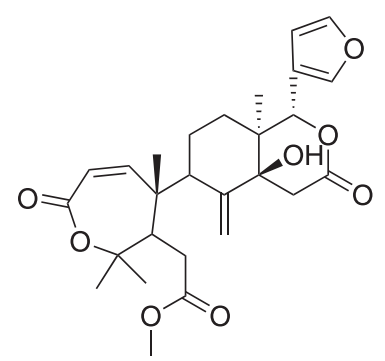

61

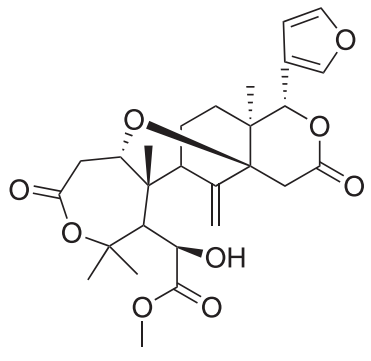

62

Figure 4. New limonoids isolated from Dictyoloma vandellianum and Sohnreyia excelsa and model compounds cneorin R (61) and khayseneganin D (62).

then EtOAc) to give $7(2.5 \mathrm{mg})$ and $\mathbf{4 7}(8 \mathrm{mg})$. Fr. 8 was chromatographed five times on Sephadex LH-20 $\left(\mathrm{CHCl}_{3}-\mathrm{MeOH}, 1: 1 ; \mathrm{MeOH} ; \mathrm{MeOH} ; \mathrm{MeOH}\right.$; then EtOAc) to give $\mathbf{4 5}(14.2 \mathrm{mg})$ and additional frs. Fr. 8.1 was then rechromatographed as above to yield $\mathbf{2 6}(5.3 \mathrm{mg})$. Fr. 10 was applied twice to Sephadex $\mathrm{LH}-20\left(\mathrm{CHCl}_{3}-\mathrm{MeOH}\right.$, 1:1; $\mathrm{MeOH}$ ) to give $70 \mathrm{mg}$ of $\mathbf{6}$. Fr. 11 and Fr. 13 were applied to Sephadex LH-20 as above to yield $\mathbf{3}(2.7 \mathrm{mg})$ and $8(5 \mathrm{mg})$, respectively. The concentrated $\mathrm{MeOH}$ extract was subjected to $\mathrm{CC}$ over cellulose. Elution with hexane, followed by a $\mathrm{CH}_{2} \mathrm{Cl}_{2}$-EtOAc-MeOH gradient yielded five frs. Fr. 2 was then rechromatographed as above to yield additional frs. Fr. 2.1 was subjected to CC over silica gel, and elution with hexane, followed by a $\mathrm{CH}_{2} \mathrm{Cl}_{2}$-EtOAc- $\mathrm{Me}_{2} \mathrm{CO}-\mathrm{MeOH}$ gradient yielded additional frs. Fr. 2.1.1 was applied to Sephadex LH-20, eluting with $\mathrm{MeOH}$ afforded a Fr. containing four compounds. It was then purified by preparative TLC (silica gel; hexaneEtOAc, 40:60) to give $\mathbf{6}(4.7 \mathrm{mg}), \mathbf{8}(3.6 \mathrm{mg}), \mathbf{5 1}(8 \mathrm{mg})$ and $57(3 \mathrm{mg})$. Fr. 3 was chromatographed twice on Sephadex $\mathrm{LH}-20\left(\mathrm{CHCl}_{3}-\mathrm{MeOH}, 1: 1\right)$ to give $74.5 \mathrm{mg}$ of $3 \beta-O-\beta$-D-glucopyranosylsitosterol.

Ground leaves $(2.9 \mathrm{~kg}$ ) from $S$. excelsa were extracted with hexane, then $\mathrm{CH}_{2} \mathrm{Cl}_{2}$ and finally with $\mathrm{MeOH}$. Fractions were monitored by ${ }^{1} \mathrm{H}$ NMR (200 MHz) and only those which showed features of limonoids, absent in the previously investigated leaves, were examined. The concentrated $\mathrm{MeOH}$ extract was subjected to $\mathrm{CC}$ over silica gel. Elution with hexane, followed by a $\mathrm{CH}_{2} \mathrm{Cl}_{2}-\mathrm{MeOH}$ gradient, yielded
16 frs. Fr. 11 was applied to $\mathrm{CC}$ over Florisil, eluted with a hexane- $\mathrm{CH}_{2} \mathrm{Cl}_{2}(1: 1), \mathrm{CH}_{2} \mathrm{Cl}_{2}-\mathrm{MeOH}$ gradient, affording additional frs. Fr. 11.1 was then rechromatographed on silica gel, eluting with a $\mathrm{CH}_{2} \mathrm{Cl}_{2}-\mathrm{MeOH}$ (95:5), and then to Sephadex $\mathrm{LH}-20(\mathrm{MeOH})$ to give the coumarin xanthyletin (7.4 mg). Fr. 11.2 was applied to CC over Florisil, eluting with hexane-EtOAc (5-50\%), and then to Sephadex LH-20 $(\mathrm{MeOH})$, and then on silica gel, eluting with hexaneEtOAc (5-50\%) to give $\mathbf{4 5}$ (3.4 mg) and two additional frs. Fr. 11.2.1 and Fr. 11.2.2 were rechromatographed on cellulose eluting with hexane- $\mathrm{CH}_{2} \mathrm{Cl}_{2}(2 \%-30 \%)$ to yield $\mathbf{5 1}$ $(6 \mathrm{mg})$ and $\mathbf{5 3}(12 \mathrm{mg})$. Fr. 11.3 was applied to $\mathrm{CC}$ over Florisil, eluted with a hexane $\mathrm{CH}_{2} \mathrm{Cl}_{2}-\mathrm{MeOH}$ gradient, and then twice on silica gel, eluted with hexane-EtOAc (5-50\%), EtOAc-MeOH and then EtOAc (5-50\%) to give $\mathbf{5 3}(80 \mathrm{mg})$ and two additional frs. Fr. 11.3.1 and Fr. 11.3.2 were rechromatographed on Sephadex LH-20 (EtOAc) to give $\mathbf{5 9}(21.4 \mathrm{mg})$ and $\mathbf{6 0}(9 \mathrm{mg})$, respectively. Fr. 14 was applied to column chromatography over Florisil, eluted with a $\mathrm{CH}_{2} \mathrm{Cl}_{2}-\mathrm{MeOH}$ (9:1), and then twice on silica gel, eluting with $\mathrm{CH}_{2} \mathrm{Cl}_{2}$-EtOAc-MeOH $(8: 2+0.5)$ to yield the flavan epicatechin and 3 $\beta-O-\beta-D-$ glucopyranosylsitosterol.

\section{1,2-Dihydro-1 $\alpha$-hydroxy-8,30-epoxy-cneorin $\mathrm{R}$ (57)}

Amorphous solid; IR (film) $v_{\max } / \mathrm{cm}^{-1} 3340$ (hydroxyl group), 1737 (this absorption indicated the presence of ester and / or lactone groups); ${ }^{1} \mathrm{H}$ NMR (300 MHz, $\mathrm{CDCl}_{3}$ ) see Table $1 ;{ }^{13} \mathrm{C}$ NMR (100 MHz, $\mathrm{CDCl}_{3}$ ) see Table 2; HSQC, HMBC (400 MHz, $\mathrm{CDCl}_{3}$ ) see text; MS / MS 
(ESI) $m / z$, found for $\left[\mathrm{C}_{27} \mathrm{H}_{36} \mathrm{O}_{10}+\mathrm{K}-\mathrm{H}_{2} \mathrm{O}\right]^{+}: 541$ (40), $\left[\mathrm{C}_{27} \mathrm{H}_{36} \mathrm{O}_{10}+\mathrm{Na}-\mathrm{H}_{2} \mathrm{O}\right]^{+}: 525$ (100), 283 (15); HRMS m/z, calcd. for $\mathrm{C}_{27} \mathrm{H}_{37} \mathrm{O}_{10}[\mathrm{M}+\mathrm{H}]^{+}:$: 521.23867, found: 521.22837 .

\section{Dictyolomin (58)}

Amorphous solid; IR (film) $v_{\max } / \mathrm{cm}^{-1} 3335$ (hydroxyl group), 1739 (this absorption indicated the presence of lactone groups); ${ }^{1} \mathrm{H} \mathrm{NMR}\left(400 \mathrm{MHz}, \mathrm{CDCl}_{3}\right)$ see Table 1; ${ }^{13} \mathrm{C}$ NMR (100 MHz, $\mathrm{CDCl}_{3}$ ) see Table 2; HSQC, HMBC, NOESY (400 MHz, $\mathrm{CDCl}_{3}$ ) see text; MS / MS (ESI) $\mathrm{m} / z$, found for $\mathrm{C}_{26} \mathrm{H}_{32} \mathrm{O}_{10}\left[\mathrm{M}+\mathrm{K}-\mathrm{H}_{2} \mathrm{O}\right]$ : 525 (100), 243 (20), 227 (65), 261 (40); HRMS m/z, calcd. for $\mathrm{C}_{26} \mathrm{H}_{31} \mathrm{O}_{9}$ $\left[\mathrm{C}_{26} \mathrm{H}_{32} \mathrm{O}_{10}+\mathrm{H}-\mathrm{H}_{2} \mathrm{O}\right]: 487.19680$, found: 487.30253 .
$3 \beta$-Angeloyloxy-7 $\alpha, 24,25$-trihydroxy-21,23-oxide-14,18cycloapotirucall-21-methoxycetal (59)

Amorphous solid; IR (film) $v_{\max } / \mathrm{cm}^{-1} 3330$ (hydroxyl group), 1704 (this absorption indicated the presence of ester group); ${ }^{1} \mathrm{H}$ NMR (400 MHz, $\mathrm{CDCl}_{3}$ ) $\delta 4.60$ (dd, $J$ 11.4, $4.7 \mathrm{~Hz}, \mathrm{H}-3), 3.75$ (bd, J $1.9 \mathrm{~Hz}, \mathrm{H}-7), 4.84$ (d, J $3.1 \mathrm{~Hz}$, H-21), 4.06 (m, H-23), 3.52 (d, J 5.3 Hz, H-24), 0.73 (d, $J 4.8 \mathrm{~Hz}, \mathrm{H}-18 \mathrm{a}$ ), 0.49 (d, J 4.8 Hz, H-18b), 0.91 (s, Me-19), 1.29 (s, Me-26), 1.20 (s, Me-27), 0.89 (s, Me-28), 0.88 (s, Me-29), 1.02 (s, Me-30), 3.36 (s, OMe), 6.02 (qq, J 7.2, 1.4 Hz, H-3'), 1.88 (brd, J 1.4 Hz, H-4'), 1.98 (brdq, J 7.2, $1.4 \mathrm{~Hz}, \mathrm{H}-5$ '); ${ }^{13} \mathrm{C}$ NMR (100 MHz, $\mathrm{CDCl}_{3}$ ) see Table 2; HSQC, HMBC (400 MHz, $\mathrm{CDCl}_{3}$ ) see text.

Table 1. ${ }^{1} \mathrm{H}$ NMR spectroscopic data for 57, 58, 60 and model 62

\begin{tabular}{|c|c|c|c|c|}
\hline \multirow{2}{*}{$\mathrm{H}$} & \multicolumn{4}{|c|}{$\delta_{\mathrm{H}} / \mathrm{ppm}(J / \mathrm{Hz})$} \\
\hline & 57 & 62 & 58 & 60 \\
\hline 1 & $4.12 \mathrm{dd}(6.0,2.0)$ & $3.38 \mathrm{dd}(5.6,2.2)$ & $3.80 \mathrm{t}(4.0)$ & $5.54 \mathrm{dd}(10.7,1.7)$ \\
\hline $2 \mathrm{a}$ & $3.24 \mathrm{dd}(15.2,2.0)$ & $3.25 \mathrm{dd}(15.2,2.2)$ & $3.14 \mathrm{~d}(4.0)$ & $3.27 \mathrm{dd}(15.8,10.7)$ \\
\hline $2 b$ & $2.97 \mathrm{dd}(15.2,6.0)$ & $2.84 \mathrm{dd}(15.2,5.6)$ & - & $2.80 \mathrm{~m}$ \\
\hline 5 & $3.03 \mathrm{dd}(8.4,2.4)$ & $3.18 \mathrm{~s}$ & $3.32 \mathrm{dd}(13.0,6.0)$ & - \\
\hline $6 a$ & $2.28 \mathrm{~m}$ & $4.25 \mathrm{~s}$ & $2.36 \mathrm{dd}(19.0,13.0)$ & $1.95 \mathrm{dd}(13.5,3.9)$ \\
\hline $6 b$ & - & - & $2.75 \mathrm{dd}(19.0,6.0)$ & $2.21 \mathrm{t}(13.5)$ \\
\hline 7 & - & - & - & $4.25 \mathrm{dd}(13.5,3.9)$ \\
\hline 9 & $1.44 \mathrm{~m}$ & $2.32 \mathrm{~d}(3.0)$ & $5.64 \mathrm{dd}(10.0,1,7)$ & $3.05 \mathrm{~d}(8.0)$ \\
\hline $11 \mathrm{a}$ & $2.40 \mathrm{~m}$ & $2.25 \mathrm{ddd}(15.1,4.6,3.0)$ & $6.00 \mathrm{ddd}(10.0,6.4,1.9)$ & $5.14 \mathrm{dd}(10.4,8.0)$ \\
\hline $11 b$ & $1.70 \mathrm{~m}$ & $1.54 \mathrm{tt}(15.1,3.5)$ & - & - \\
\hline $12 \mathrm{a}$ & $1.98 \mathrm{~m}$ & $1.91 \mathrm{dt}(13.5,4.6)$ & $1.70 \mathrm{~m}$ & 1.66 brd (14.1) \\
\hline $12 b$ & $1.17 \mathrm{~m}$ & $1.04 \mathrm{dd}(13.5,3.5)$ & $2.30 \mathrm{~m}$ & $2.80 \mathrm{~m}$ \\
\hline $15 \mathrm{a}$ & $2.63 \mathrm{~d}(19.0)$ & $2.93 \mathrm{~d}(18.2)$ & $3.42 \mathrm{~d}(19.0)$ & $3.38 \mathrm{brs}$ \\
\hline $15 b$ & $2.17 \mathrm{~d}(19.0)$ & $2.56 \mathrm{~d}(18.2)$ & $3.10 \mathrm{~d}(19.0)$ & - \\
\hline $16 \mathrm{a}$ & - & - & - & $1.81 \mathrm{~m}$ \\
\hline $16 b$ & - & - & - & $2.45 \mathrm{~m}$ \\
\hline 17 & $5.76 \mathrm{~s}$ & $5.67 \mathrm{~s}$ & $5.73 \mathrm{~s}$ & $2.45 \mathrm{~m}$ \\
\hline $21 \mathrm{a}$ & 7.52 brs & $7.46 \mathrm{~s}$ & $7.43 \mathrm{~m}$ & $4.43 \mathrm{t}(9.0)$ \\
\hline 20 & - & - & - & $2.80 \mathrm{~m}$ \\
\hline $21 b$ & - & - & - & $3.82 \mathrm{t}(9.0)$ \\
\hline 22 & 6.44 brs & $6.40 \mathrm{~d}(1.5)$ & $6.38 \mathrm{brs}$ & $2.45 \mathrm{~m}$ \\
\hline 23 & $7.40 \mathrm{t}(1.8)$ & $7.38 \mathrm{t}(1.5)$ & $7.41 \mathrm{~m}$ & - \\
\hline 18 & $0.93 \mathrm{~s}$ & $0.88 \mathrm{~s}$ & $1.12 \mathrm{~s}$ & $1.18 \mathrm{~s}$ \\
\hline 19 & $1.19 \mathrm{~s}$ & $1.29 \mathrm{~s}$ & $1.30 \mathrm{~s}$ & $1.17 \mathrm{~s}$ \\
\hline 28 & $1.36 \mathrm{~s}$ & $1.38 \mathrm{~s}$ & $1.52 \mathrm{~s}$ & $1.43 \mathrm{~s}$ \\
\hline 29 & $1.62 \mathrm{~s}$ & $1.79 \mathrm{~s}$ & $1.32 \mathrm{~s}$ & $1.70 \mathrm{~s}$ \\
\hline $30 \mathrm{a}$ & $2.74 \mathrm{~s}$ & $4.92 \mathrm{~s}$ & $4.21 \mathrm{~s}$ & $1.84 \mathrm{~d}(16.1)$ \\
\hline $30 \mathrm{~b}$ & - & $5.20 \mathrm{~s}$ & - & $2.87 \mathrm{~d}(16.1)$ \\
\hline $\mathrm{OMe}$ & $3.71 \mathrm{~s}$ & $3.85 \mathrm{~s}$ & - & $3.65 \mathrm{~s}$ \\
\hline $14-\mathrm{OH}$ & - & - & $2.86 \mathrm{~s}$ & - \\
\hline OAc / C-1 & - & - & - & $2.08 \mathrm{~s}$ \\
\hline OAc / C-11 & - & - & - & $1.98 \mathrm{~s}$ \\
\hline
\end{tabular}

$\delta_{\mathrm{H}}$ : hydrogen chemical shift; $J$ : coupling constant; dd: doublet of doublet; t: triplet; d: doublet; m: multiplet; s: singlet; tt: triplet of triplet; dt: doublet of triplet; brd: broad doublet; brs: broad singlet. ${ }^{1} \mathrm{H}$ NMR spectra were acquired in $\mathrm{CDCl}_{3}$ at $300 \mathrm{MHz}(\mathbf{5 7}), 400 \mathrm{MHz}(\mathbf{5 8}, \mathbf{6 0})$ and $500 \mathrm{MHz}(\mathbf{6 2})$. TMS was used as internal standard. Assignments are based on COSY, HSQC and HMBC experiments. 
Table 2. ${ }^{13} \mathrm{C}$ NMR spectroscopic data for 57-60 and model 62

\begin{tabular}{|c|c|c|c|c|c|}
\hline \multirow{2}{*}{$\mathrm{C}$} & \multicolumn{5}{|c|}{$\delta_{\mathrm{C}} / \mathrm{ppm}$} \\
\hline & 57 & 62 & 58 & 60 & 59 \\
\hline 1 & 71.7 & 74.3 & 69.6 & 72.3 & 38.2 \\
\hline 2 & 37.6 & 38.4 & 37.3 & 35.1 & 24.2 \\
\hline 3 & 170.0 & 171.0 & 169.2 & 171.1 & 80.6 \\
\hline 4 & 83.7 & 84.2 & 82.3 & 64.8 & 37.4 \\
\hline 5 & 43.9 & 49.2 & 37.8 & 66.2 & 43.9 \\
\hline 6 & 35.9 & 71.0 & 30.6 & 32.2 & 26.3 \\
\hline 7 & 173.5 & 176.3 & 169.0 & 80.2 & 74.2 \\
\hline 8 & 60.5 & 146.2 & 70.0 & 84.6 & 38.9 \\
\hline 9 & 48.0 & 56.2 & 124.3 & 50.4 & 46.1 \\
\hline 10 & 47.1 & 48.6 & 41.1 & 43.9 & 36.2 \\
\hline 11 & 22.3 & 24.5 & 129.5 & 69.5 & 16.3 \\
\hline 12 & 28.0 & 28.6 & 31.1 & 45.5 & 23.6 \\
\hline 13 & 42.7 & 42.1 & 39.4 & 43.4 & 28.5 \\
\hline 14 & 78.6 & 81.4 & 78.9 & 67.5 & 37.2 \\
\hline 15 & 31.6 & 34.4 & 30.1 & 68.7 & 25.5 \\
\hline 16 & 169.3 & 170.1 & 169.2 & 29.7 & 25.8 \\
\hline 17 & 79.0 & 79.6 & 79.0 & 52.9 & 48.6 \\
\hline 18 & 13.5 & 14.2 & 15.7 & 19.6 & 13.6 \\
\hline 19 & 24.1 & 24.1 & 19.7 & 18.8 & 15.8 \\
\hline 20 & 120.4 & 121.1 & 120.3 & 38.6 & 49.5 \\
\hline 21 & 141.0 & 141.4 & 141.2 & 73.1 & 108.6 \\
\hline 22 & 110.0 & 110.4 & 110.0 & 32.8 & 32.4 \\
\hline 23 & 142.7 & 143.1 & 142.9 & 176.7 & 77.6 \\
\hline 24 & - & - & - & - & 77.9 \\
\hline 25 & - & - & - & - & 72.1 \\
\hline 26 & - & - & - & - & 26.8 \\
\hline 27 & - & - & - & - & 25.0 \\
\hline 28 & 31.6 & 31.9 & 22.4 & 22.9 & 17.0 \\
\hline 29 & 22.4 & 27.0 & 32.1 & 24.2 & 27.8 \\
\hline 30 & 48.9 & 112.5 & 90.7 & 42.2 & 19.4 \\
\hline $\mathrm{OMe}$ & 52.2 & 54.0 & & 51.9 & 55.6 \\
\hline OAc & - & - & - & C-1, $170.4 / 21.5$ & - \\
\hline $\mathrm{OAc}$ & - & - & - & C-11, $170.8 / 20.2$ & - \\
\hline OCOO & - & - & - & 151.9 & - \\
\hline 1 ' & - & - & - & - & 167.8 \\
\hline 2 & - & - & - & - & 128.5 \\
\hline 3 , & - & - & - & - & 137.1 \\
\hline $4^{\prime}$ & - & - & - & - & 20.7 \\
\hline 5, & - & - & - & - & 15.8 \\
\hline
\end{tabular}

$\delta_{\mathrm{C}}$ : carbon chemical shift. ${ }^{13} \mathrm{C}$ NMR spectrum was acquired in $\mathrm{CDCl}_{3}$ at $100 \mathrm{MHz}(\mathbf{5 7 - 6 0})$ and $125 \mathrm{MHz}(\mathbf{6 2})$. Assignments are based on HSQC and $\mathrm{HMBC}$ experiments.

\section{Sohnreyolide (60)}

Amorphous solid; IR (film) $v_{\max } / \mathrm{cm}^{-1} 1808,1770$, 1745 (these absorptions indicated the presence of carbonate substituent, ester and lactone groups); ${ }^{1} \mathrm{H}$ NMR (400 MHz, $\mathrm{CDCl}_{3}$ ) see Table $1 ;{ }^{13} \mathrm{C}$ NMR $\left(100 \mathrm{MHz}, \mathrm{CDCl}_{3}\right)$ see Table 2; HSQC, HMBC, NOESY (400 MHz, $\mathrm{CDCl}_{3}$ ) see text; MS / MS (ESI) $m / z$, found for $\mathrm{C}_{32} \mathrm{H}_{42} \mathrm{O}_{13}[\mathrm{M}+\mathrm{H}]$ :
635 (100), $\left[\mathrm{M}+\mathrm{H}-\mathrm{CO}_{3}\right]: 575$ (10); $\mathrm{HRMS} \mathrm{m/z,} \mathrm{calcd.} \mathrm{for}$ $\mathrm{C}_{32} \mathrm{H}_{43} \mathrm{O}_{13}\left[\mathrm{C}_{32} \mathrm{H}_{42} \mathrm{O}_{13}+\mathrm{H}\right]:$ 635.27036, found: 635.28010.

Unfortunately the mass error for the HRMS spectra of all compounds were high, but the obtained low resolution ESI-MS / MS, 1D and 2D NMR (HSQC, HMBC) data confirmed the structures.

\section{Results and Discussion}

\section{Isolated compounds}

In a continuation of our investigation of the leaves of D. vandellianum, we have isolated from the dichloromethane extract the known sitosterol, 2-quinolinone alkaloid 8-methoxyflindersine (6), and a new limonoid (58) (Figure 4). The methanol extract afforded the limonoid deacetylspathelin (45).

The dichloromethane extract from heartwood yielded 2-quinolinone alkaloids 4,7,8-trimethoxy-1-methyl2-quinolinone (3), 6, 8-methoxy- $N$-methylflindersine (7), 7,8-dimethoxyflindersine (8), prenylated chromone 6-(3-methylbut-2-enyl)allopeteroxylin methyl ether (26) and limonoids deacetylspathelin (45), 21,23-dihydro21-hydroxy-23-oxo-deacetylspathelin (47). The methanol extract gave $3 \beta-O-\beta$-D-glucopyranosylsitosterol, 2-quinolinone alkaloids 6 and $\mathbf{8}$, limonoids limonin diosphenol (51), and $\mathbf{5 7}$ which is an unpublished limonoid.

The new limonoids were identified as $\mathbf{5 7}$ and $\mathbf{5 8}$ on the basis of the following data. The ${ }^{1} \mathrm{H}$ NMR spectra of both limonoids indicated the presence of three downfield shifted signals attributable to a $\beta$-substituted furan ring $(\delta 7.52,6.44,7.40$ for $\mathbf{5 7}$, and $\delta 7.43,6.38,7.41$ for $\mathbf{5 8}$ ), one signal characteristic of protons attached to a carbon adjacent to an oxygen atom of a carboxyl group $(\delta 5.76$ for 57, $\delta 5.73$ for 58), and two isolated methylenes ( $\delta$ 2.63, 2.17, d, $J 19 \mathrm{~Hz}$ for $\mathbf{5 7} ; \delta 3.42,3.10, \mathrm{~d}, J 19 \mathrm{~Hz}$ for $\mathbf{5 8}$ ) (Table 1). The large geminal coupling constant of these methylene protons was consistent with their situation $\alpha$ to a carboxyl group and with C-14 fully substituted. From HMBC spectra the observed correlation between the ${ }^{1} \mathrm{H}$ signal at $\delta 5.76$ for $\mathbf{5 7}$ and $\delta 5.73$ for $\mathbf{5 8}$, assigned to $\mathrm{H}-17$, and the ${ }^{13} \mathrm{C}$ signal at $\delta 141.0$ for $\mathbf{5 7}$ and $\delta 141.2$ for $\mathbf{5 8}$ (C-21) determined the position of furan ring at $\mathrm{C}-17$. The correlation of the methylene signals to the $\mathrm{C}-16$ signal at $\delta_{\mathrm{C}} 169.3$ for $\mathbf{5 7}$ and $\delta 169.2$ for $\mathbf{5 8}$, as well as of the C-18 signal at $\delta 0.93$ for $\mathbf{5 7}$ and $\delta 1.12$ for $\mathbf{5 8}$ to the oxygenbearing C-14 signal at $\delta_{\mathrm{C}} 78.6$ for $\mathbf{5 7}$ and $\delta_{\mathrm{C}} 78.9$ for $\mathbf{5 8}$, suggesting the presence of a D 14-hydroxylactone. The signals at $\delta 2.63,2.17, \mathrm{~d}, J 19 \mathrm{~Hz}$ for $57 ; \delta 3.42,3.10$, d, $J 19 \mathrm{~Hz}$ for $\mathbf{5 8}$ were then assigned to H-15a and H-15b, respectively. 
The principal change observed in the ${ }^{13} \mathrm{C}$ NMR spectrum of limonoid isolated from heartwood (57) was the resonance for an epoxy methylene $\delta_{\mathrm{H}} 2.74$, brs, $\delta_{\mathrm{C}} 48.9$. The signal for $\mathrm{H}-15 \mathrm{~b}$ at $\delta 2.17$ and the methylene signal at $\delta_{\mathrm{H}} 2.74$ showed correlation with the ${ }^{13} \mathrm{C}$ signal at $\delta 60.5$, suggesting the presence of an epoxy formed by $\mathrm{C}-30$ and $\mathrm{C}-8$, and requiring the ring $\mathrm{B}$ cleaved. The $\mathrm{C}-18$ signal at $\delta 0.93$ showed cross peaks with the ${ }^{13} \mathrm{C}$ signal at $\delta 28.0$, which correlated in the HSQC with the ${ }^{1} \mathrm{H}$ signals at $\delta$ $1.98, \mathrm{~m}(\mathrm{H}-12 \mathrm{a})$ and $1.17, \mathrm{~m}(\mathrm{H}-12 \mathrm{~b})$, and the last two were coupled to the ${ }^{1} \mathrm{H}$ signals at $\delta 2.40, \mathrm{~m}(\mathrm{H}-11 \mathrm{a})$ and $1.70, \mathrm{~m}$ (H-11b) (by correlation spectroscopy (COSY)), confirming the intact ring C. Comparison of the NMR data of $\mathbf{5 7}$ with those of cneorin $\mathrm{R}(\mathbf{6 1} ; \mathrm{H}-17, \delta 5.65$ (s), 78.0; C-7 $\delta$ 173.9, $\mathrm{OMe}, 3.70,51.8)^{37}$ indicated that $\mathbf{5 7}$ has a similar ring A. The differences were the presence of a secondary hydroxyl $\left(\delta_{\mathrm{H}} 4.12, \mathrm{dd}, J 6.0,2.0 \mathrm{~Hz} ; \delta_{\mathrm{C}} 71.7\right)$ and the absence of a double-bond at C-1. This was supported by the ESI-MS / MS low resolution which indicated the molecular formula to be $\mathrm{C}_{27} \mathrm{H}_{36} \mathrm{O}_{10}$, and provides fragments by loss of a neutral $\mathrm{H}_{2} \mathrm{O}$ at $m / z, 525\left[\mathrm{C}_{27} \mathrm{H}_{36} \mathrm{O}_{10}+\mathrm{Na}-\mathrm{H}_{2} \mathrm{O}\right]^{+}(100 \%)$ and $\mathrm{m} / z .541$ $\left[\mathrm{C}_{27} \mathrm{H}_{36} \mathrm{O}_{10}+\mathrm{K}-\mathrm{H}_{2} \mathrm{O}\right]^{+}(40 \%)$, by cleavage at $\mathrm{C}-\mathrm{C}$ bond between ring $\mathrm{A}$ and $\mathrm{C}$ at $\mathrm{m} / \mathrm{z} 283$, giving a good indication of the substitution patterns of A-B $(\mathrm{m} / \mathrm{z} 244+\mathrm{K}=283)$ and $\mathrm{C}-\mathrm{D}$ rings $(\mathrm{m} / \mathrm{z}, 260+\mathrm{Na}=283)$ (Scheme 1$)$. In the NOESY experiments the H-1 signal did not influence any group with a spatial proximity such as Me-19, and the hydroxyl hydrogen at C-14 was not detected. Thus, this experiment did not facilitate elucidation of the relative configuration of C-1 and C-14, thus the stereochemistry suggested for 57 was based on the biosynthesis of limonoids. However, for $\mathrm{C}-1$ the coupling constants between $\mathrm{H}-1$ and $\mathrm{H}-2 \mathrm{a}$ and $\mathrm{H}-2 \mathrm{~b}$ were characteristic of $1 \alpha$-oxygenated derivative as in khayseneganin D (62) (Table 1). ${ }^{38}$ The new limonoid was therefore identified as 1,2-dihydro- $1 \alpha$-hydroxy8,30-epoxy-cneorin R (57). The structural assignment was also supported by comparison of the NMR data with those of khayseneganin D (62). ${ }^{38}$

In limonoid 58 the Me-18 signal at $\delta 1.12$ showed cross peaks with the ${ }^{13} \mathrm{C}$ signal at $\delta 31.0$, which correlated in the HSQC with the ${ }^{1} \mathrm{H}$ signals at $\delta 2.30, \mathrm{~m}(\mathrm{H}-12 \mathrm{~b})$ and $1.70, \mathrm{~m}$ (H-12a), and the latter two were coupled to the ${ }^{1} \mathrm{H}$ signals at $\delta 6.00$ (ddd, $J 10.0,6.4,1.9 \mathrm{~Hz}$ ), and this was coupled to another olefinic hydrogen at $\delta 5.64(\mathrm{dd}, J 10.0,1.7 \mathrm{~Hz})$,

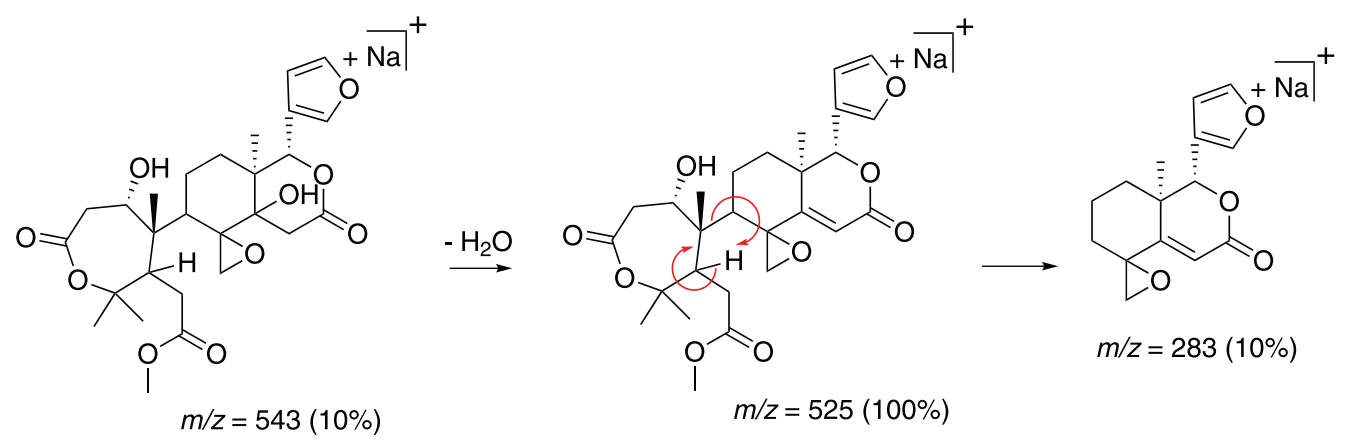

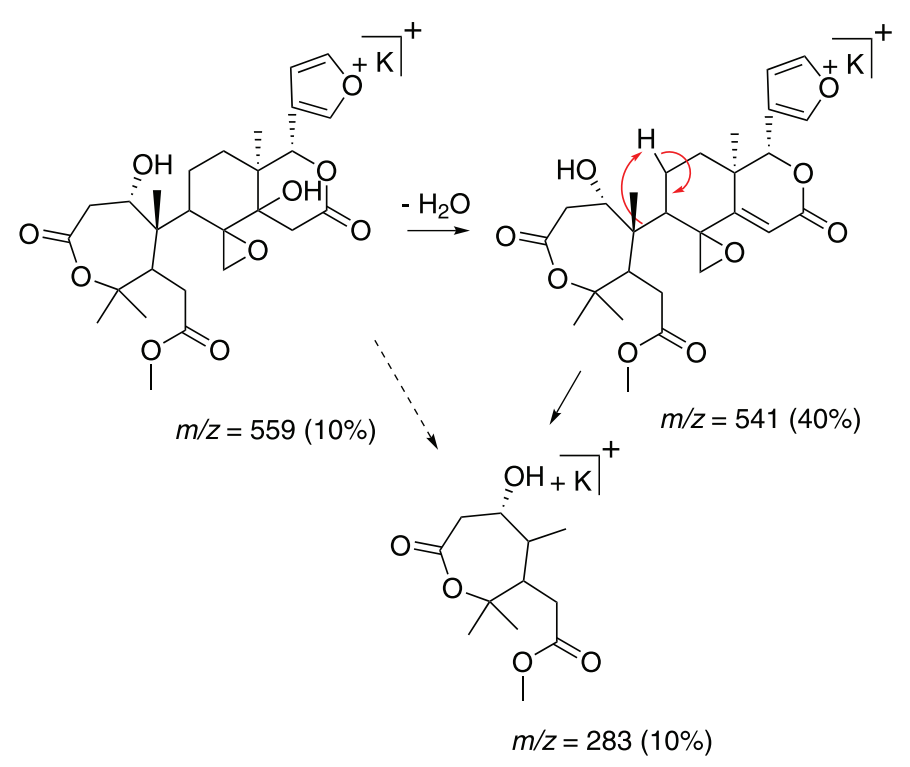

Scheme 1. ESI-MS fragmentation patterns for limonoid 57. 
ascribed to $\mathrm{H}-11$ and $\mathrm{H}-9$, respectively. These observations could not be explained by the presence of ring $\mathrm{C}$ as in $\mathbf{5 7}$. Indicating that we were not dealing with a normal B-seco limonoid. The strained three membered ring of epoxide makes it highly susceptible to ring opening reactions, and this may have occurred. Acid can catalyze the ring opening by cleavage of the carbon-oxygen bond (C-30-O-C-8) in 57. However, the processes may be a concerted reaction, and the molecular fragment ring $\mathrm{A}$ by $\mathrm{C}-10$ acting as a nucleophile attacks the protonated epoxide at $\mathrm{C}-30$, with concomitant abstraction of hydrogen from C-11 to form a double bond between C-11 and C-9, and yielding an alcohol at C-8 (see biosynthesis proposal later, and Scheme 2).

The chemical shift of C-8 was established as $\delta 70.0$ via correlation in HMBC between $\mathrm{H}-11(\delta 6.00)$ and $\mathrm{C}-8$ (quaternary). In the same way, C-30 emerged from the correlation between $\mathrm{H}-9(\delta 5.64)$ and the carbon at $\delta 90.7$ (CH by HSQC, $\delta 4.21, \mathrm{~s})$. The deshielded resonance for $\mathrm{C}-30$ and $\mathrm{H}-30$ indicated the presence of a lactone involving an intramolecular esterification by secondary hydroxyl at C-30 and C-7 carboxylic ester. This was supported by the correlations of the $\mathrm{H}-30$ signal at $\delta 4.21$, and the ${ }^{1} \mathrm{H}$ signals at $\delta 2.36$ and 2.75 (attributed to $\mathrm{H}_{2}-6$ ) to $\delta 169.0$, which confirm ring B lactone with $\mathrm{C}-30-\mathrm{O}-$, and permitting the assignment of the signal at $\delta 169.0$ to $\mathrm{C}-7$. These data suggest that ring A via a carbanion at C-10 migrated to C-30 and subsequent oxidation of C-30 to an alcohol occurred (Scheme 2).

Moreover, the $\mathrm{H}_{3}-28$ and $\mathrm{H}_{3}-29$ at $\delta 1.52$ and 1.32 showed cross peaks with the ${ }^{13} \mathrm{C}$ signal at $\delta 82.3$ (quaternary), thus indicating ring A as a lactone. Hydroxyl must be connected at $\mathrm{C}-1$ due to the observed correlation between $\mathrm{H}-1$ at $\delta 3.80$ and the carbon at $\delta 169.2$, attributed to $\mathrm{C}-3$. Finally, the cross peak of $\mathrm{H}-30(\delta 4.21)$ with the ${ }^{13} \mathrm{C}$ signal of $\mathrm{C}-1$ at $\left.\delta 69.6{ }^{3} \mathrm{~J} \mathrm{H}-30 \rightarrow \mathrm{C}-10 \rightarrow \mathrm{C}-1\right)$ confirms the new bond between $\mathrm{C}-10$ and $\mathrm{C}-30$.

Considering that the rearrangement process in terms of orbitals leads to the prediction that the configuration of the migrating group will be retained in the transition, ${ }^{39}$ and based on the biosynthesis of limonoids, the methyl group bonded to carbon 10 remains on face $\beta$ at the junction of rings $\mathrm{A}$ and $\mathrm{B}$. Recall that by definition, the Me-19 is on face $\beta$ and Me-18 and furan ring on face $\alpha$ of a limonoid, allowing to propose the relative stereochemistry of a limonoid using the nuclear Overhauser effects (NOE). Thereat, the NOESY experiments showed correlations between $\mathrm{H}-1$ and $\mathrm{H}-30$ with $\mathrm{H}_{3}-19$, implying that $\mathrm{H}-1$ and $\mathrm{H}-30$ were on the $\beta$-side of the rings A-B. In nuclear Overhauser effect difference (NOEDIFF) experiments the NOE of the hydroxyl proton at $\delta 2.86(\mathrm{C} 14-\mathrm{OH})$, coming from $\mathrm{H}_{3}-18$ showed that the hydroxyl group at $\mathrm{C}-14$ is thus in the $\alpha$-configuration. The hydroxyl hydrogen at $\mathrm{C}-8$ was not detected, thus the NOESY experiments did not facilitate elucidation of the relative configuration of C-8. A possible pathway leading to the formation of 1,2-dihydro$1 \alpha$-hydroxy-8,30-epoxy-cneorin $\mathrm{R}(57)$ and dictyolomin (58) cannot be prosed from the more usual 14,15 $\beta$-epoxide limonoids, since in both compounds the hydroxyl at C-14 appear to be on face $\alpha$ of limonoids. Thus we suggest as precursor methyl ivorensate (63), which has a $1 \alpha, 14 \beta$ ether

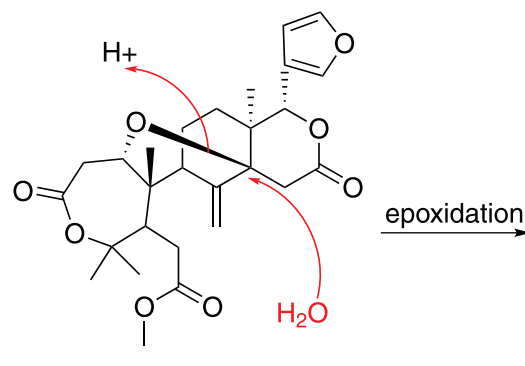

63

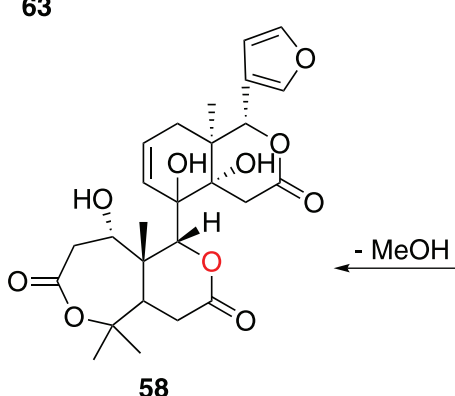

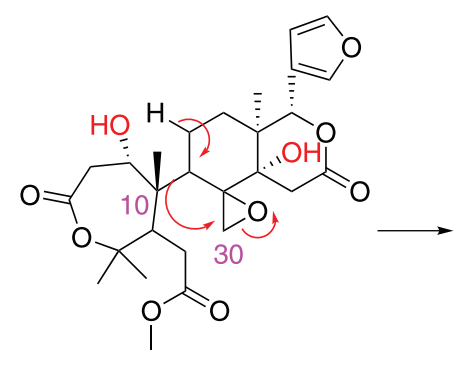

57

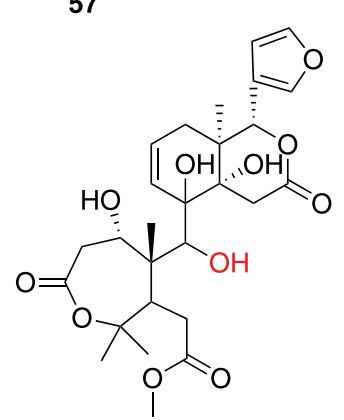

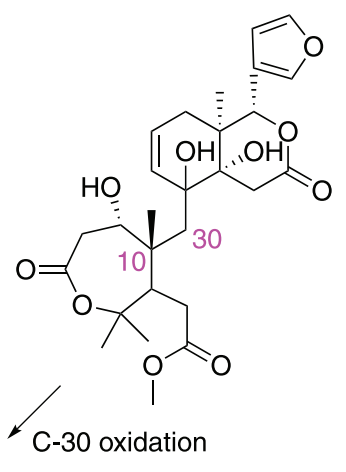

configuration of C-14 in 57, based on biogenesis this was proposed as being $\mathrm{C} 14 \alpha-\mathrm{OH}$. 
ring, and opening this ether group by water nucleophile attack at $\mathrm{C}$ - 14 leads to the invariable $\alpha$-hydroxyl functions at C-1 and C-14. Epoxidation of 8,30 double bond affords $\mathbf{5 7}$, and this leading to $\mathbf{5 8}$ is illustrated in Scheme 2.

Limonoid 58 failed to give an $[\mathrm{M}]^{+}$in the HRMS and in the ESI-MS / MS, the largest fragment observed being $m / z 487.30253\left[\mathrm{C}_{26} \mathrm{H}_{32} \mathrm{O}_{10}+\mathrm{H}-\mathrm{H}_{2} \mathrm{O}\right]$, and $m / z, 525\left[\mathrm{C}_{26} \mathrm{H}_{32} \mathrm{O}_{10}, \mathrm{M}+\mathrm{K}-\mathrm{H}_{2} \mathrm{O}\right]$, respectively. The ESI-MS / MS also showed ions at $\mathrm{m} / \mathrm{z}, 243,227$ and 261 , confirming the substituents at rings $A B$ and $C D$ (Scheme 3). Thus, the structure of the new limonoid was characterized as $1 \alpha, 8,14 \alpha$-trihydroxy-8-(30-oxa10,5,6,7-cyclohexan-7-one-9,11-en-3,4-lactone)-limonoid, and named dictyolomin (58).

We have also undertaken a further investigation of $S$. excelsa, and the methanol extract from leaves afforded the known 3 $\beta$-O- $\beta$-D-glucopyranosylsitosterol, the coumarin xanthyletin, ${ }^{26}$ the flavan epicatechin, ${ }^{40}$ limonoids deacetylspathelin (45), limonin diosphenol (51), perforatin (53), the new protolimonoid $\mathbf{5 9}$ and the new limonoid $\mathbf{6 0}$.

Protolimonoid 59 exhibited similar NMR spectra to $3 \beta$-angeloyloxy-7 $\alpha, 24,25$-trihydroxy-21,23-oxide14,18-cycloapotirucall-21-hemiacetal (44), except for the presence of a methoxyl group $\left(\delta_{\mathrm{H}} 3.36, \delta_{\mathrm{C}} 55.6\right)$ (Table 2). The HMBC spectrum showed correlation from methoxyl signal $\left(\delta_{\mathrm{H}} 3.36\right)$ to the $\mathrm{C}-21$ signal at $\delta_{\mathrm{C}} 108.6$, so placing the methoxyl substituent at $\mathrm{C}-21$. The deshielded resonance observed for C-21 is typical of a ketal function and identifies this compound as $3 \beta$-angeloyloxy-7 $\alpha, 24,25$-trihydroxy21,23-oxide-14,18-cycloapotirucall-21-methoxycetal (59).

Limonoid 60 instead of showing signals for a furan ring, it showed signals for a $\gamma$-lactone $(\mathrm{H}-20, \delta 2.80(\mathrm{~m})$; C-20, $\delta$ 38.6; H-21a, $\delta 4.43$ (brt, $J 9.0$ Hz); H-21b, $\delta 3.82$ (brt, $J$ 9.0 Hz); C-21, $\delta 73.1 ; \mathrm{H}-22, \delta 2.45$, m; C-22, $\delta 32.8$; C-23, $\delta$ 176.7; assignments based on HSQC and HMBC). $\gamma$-Lactones and $\gamma$-hydroxybutenolides appear to represent stages between the intact side-chain and furan ring (protolimonoid to limonoid), however literature has shown that they also arise by oxidation of the furan ring. ${ }^{14}$ Compound 60 showed the spectroscopic characteristics of a ring A cleaved limonoid, thus we consider it a member of this class. In HMBC the cross peak of H-21b ( $\delta 3.82)$ with the ${ }^{13} \mathrm{C}$ signal at $\delta 52.9$ of $\mathrm{C}-17$ confirms the $\gamma$-lactone at C-17. The signal of $\mathrm{H}-17\left(\delta_{\mathrm{H}} 2.45, \mathrm{~m}\right)$ showed correlation with ${ }^{13} \mathrm{C}$ signal at $\delta 68.7$ (H-15, $\delta 3.38$, brs) and with Me-18 signal at $\delta 19.6$, whose hydrogen signal at $\delta 1.80$ was correlated to the ${ }^{13} \mathrm{C}$ signal at $\delta 67.5$ (quaternary, C-14),

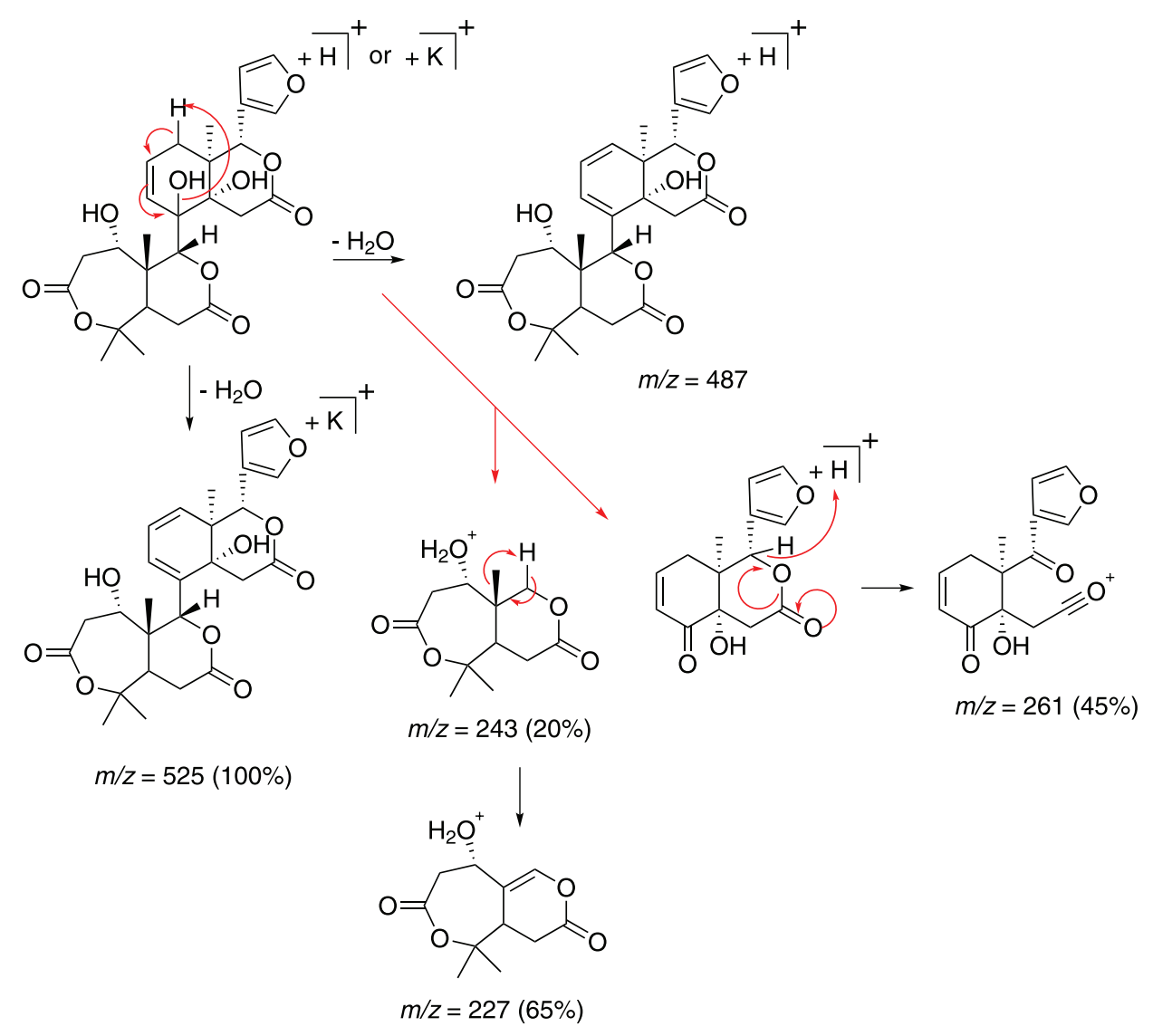


confirming the presence of a D-five-membered ring with a 14,15-epoxide group.

The identification of the ring A cleaved was supported by comparison of the NMR data with those of deacetylspathelin (45). The ${ }^{1} \mathrm{H}$ NMR spectrum instead of signals for a 1-en3-carbometoxy, showed a signal for an oxymethine proton at $\delta 5.54(\mathrm{dd}, J 10.7$ and $1.7 \mathrm{~Hz})$ and for an acetoxyl group $\left(\mathrm{Me} \delta_{\mathrm{H}} 2.08, \mathrm{~s} ; \mathrm{Me}-\mathrm{COO}-\delta_{\mathrm{C}} 21.5\right.$ and 170.4). This signal showed correlations with Me-19 signal at $\delta_{\mathrm{C}} 18.8$, determining the position of the acetoxyl at C-1. A second oxymethine proton at $\delta 5.14(\mathrm{dd}, J 10.4$ and $8.0 \mathrm{~Hz})$ was coupled to the ${ }^{1} \mathrm{H}$ signals at $\delta 3.05(\mathrm{H}-9, \mathrm{~d}, J 8.0 \mathrm{~Hz})$, which showed correlation with Me-19 signal $\left(\delta_{\mathrm{C}} 18.8\right)$, indicating an acetoxyl group ( $\mathrm{Me} \delta_{\mathrm{H}} 1.98$, s; Me-COO- $\delta_{\mathrm{C}} 20.2$ and $170.8)$ to be located at $\mathrm{C}-11$. In addition, the signal for H-7 $\left(\delta 4.25\right.$, dd, $J 13.5$ and $\left.3.9 \mathrm{~Hz} ; \delta_{\mathrm{C}} 80.2\right)$ was coupled to $\mathrm{H}-6 \mathrm{a}(\delta 1.95$, dd, $J 13.5$ and $3.9 \mathrm{~Hz})$ and $\mathrm{H}-6 \mathrm{~b}(\delta 2.21$, $\mathrm{t}, J 13.5 \mathrm{~Hz}$ ), which were correlated with the signal for C-5 ( $\delta$ 66.2), confirming oxygen substituents at C-5 and C-7. The signal for H-7 also showed correlation with a ${ }^{13} \mathrm{C}$ signal at $\delta 151.9$ suggesting a carbon-carbon double bond; however the NMR data did not indicate the presence of the second olefinic carbon, thus suggesting a carbonate substituent, whose chemical shift is normally around $\delta 149 .{ }^{41}$ Moreover, the ${ }^{1} \mathrm{H}$ NMR spectrum suggested the presence of isolated methylene protons ( $\delta 1.18$ and 2.87 , d, $\left.J 16.1 \mathrm{~Hz} ; \delta_{\mathrm{C}} 42.3\right)$ in ring $\mathrm{C}$, since it was the only location left in the skeleton. These signals showed correlation with the signals for $\mathrm{C}-14\left(\delta\right.$ 67.5) and $\mathrm{C}-15(\delta 68.7)$. The ${ }^{1} \mathrm{H}$ signal of $\mathrm{H}-7$ was correlated to ${ }^{13} \mathrm{C}$ signal for this methylene
$\delta_{\mathrm{C}}$ 42.3. Only an expansion of the $\mathrm{C}$ ring could explain these data, and it included C-30, since the HMBC did not indicate Me-30 at C-8. Similar expansion occurred for the delevoyin C limonoid isolated from Entandrophragma delevoyi, Meliaceae. ${ }^{42}$ The expansion of the $\mathrm{C}$ ring of a 7 -carbonateseco-ringA-tetranorapotirucallane precursor (64) may have occurred, resulting in structure 60, whose spectroscopic properties are in accordance with the above data and with one more ${ }^{13} \mathrm{C}$ signal at $\delta 84.6$, attributed to $\mathrm{C}-8$ (Scheme 4 ). The cross peak from $\mathrm{H}-30$ at $\delta 2.87$ to C-8 confirm this attribution. The ESI-MS indicated the molecular formula to be $\mathrm{C}_{32} \mathrm{H}_{42} \mathrm{O}_{13}(\mathrm{~m} / z 635, \mathrm{M}+\mathrm{H})$, and the fragment at $m / z, 575\left[\mathrm{M}+\mathrm{H}-\mathrm{CO}_{3}\right]$ confirms the presence of a carbonate substituent. The configuration suggested for $\mathbf{6 0}$ was based on the biosynthesis of limonoids, however, these were supported by NOESY experiments. The correlation between the signals $\mathrm{H}-7 \rightarrow \mathrm{Me}-19$ indicates that $\mathrm{H}-7$ is on the face $\beta$ of the molecule, whereas those between H-15 $\rightarrow$ Me-18, and H-11 $\rightarrow$ H-9 and $\rightarrow$ Me-18 indicate that $\mathrm{H}-15$ and $\mathrm{H}-11$ are on the face $\alpha$ of the structure. Limonoid $\mathbf{6 0}$ was then established as $1,11 \beta$-diacetoxy-4,5,14 $\beta, 15 \beta$-diepoxy- $7 \alpha, 8 \alpha$-carbonate$17 \alpha$-(21,24- $\gamma$-lactone)-8,9,11,12,13,14,30-cycloheptanyl3,4-secotirucalla-3-methylester, and named as sohnreyolide (60).

\section{Chemosystematic considerations}

The finding of 2-alkyl-4(1H)-quinolones in Dictyoloma vandellianum and Sohnreyia excelsa (synonym

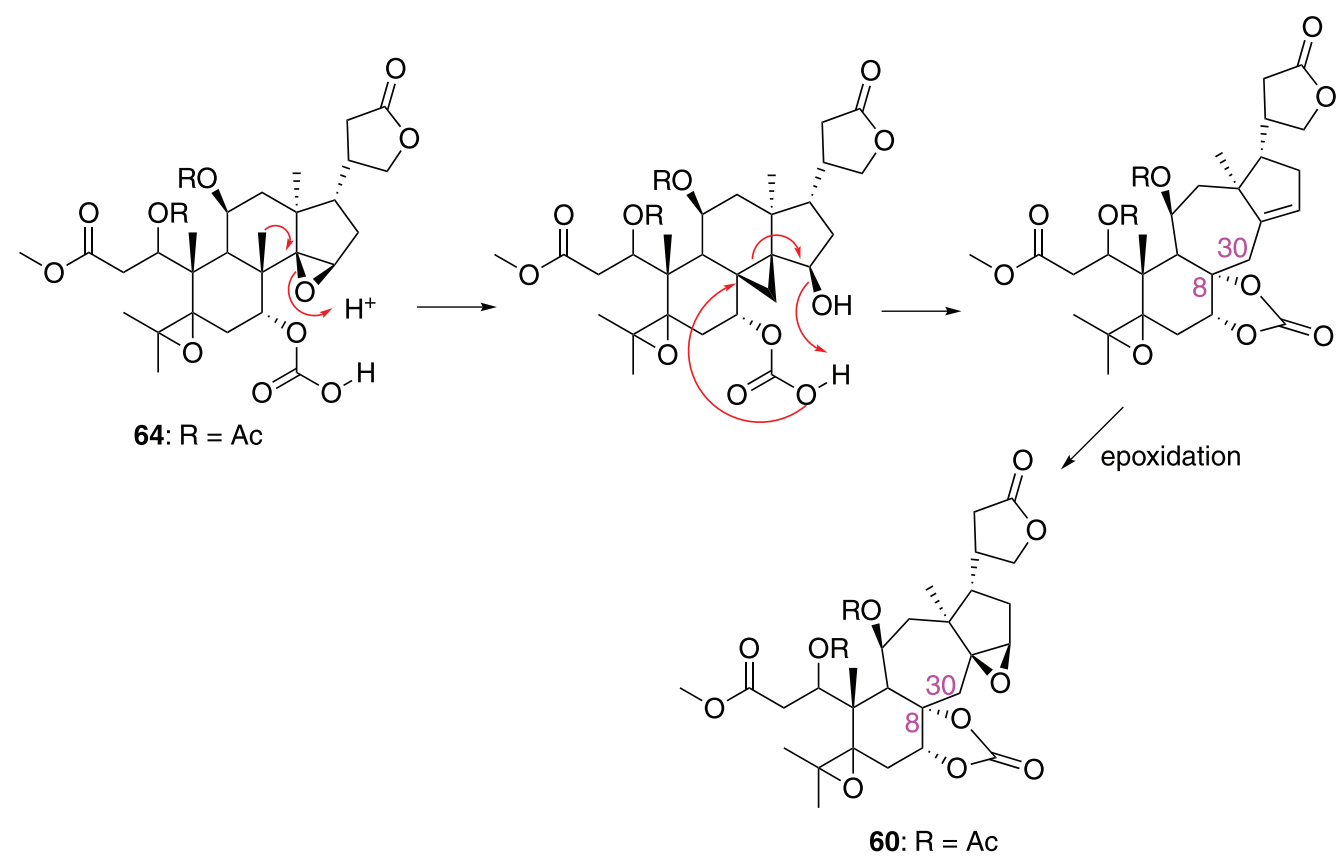

Scheme 4. Probable biogenetic route to limonoid 60. 
Spathelia excelsa) shows strong similarities of both with Zanthoxyleae [Platydesma and Tetradium (T. ruticarpum = Euodia rutaecarpa)], Ruteae (Haplophyllum and Ruta), Boronieae (Boronia), Cusparieae (Raulinoa), Toddalieae (Acronychia, Vepris and Ptelea), which contain several 2-alkyl-4-quinolones. ${ }^{16,25,29,43}$

The limonoid constituents from both genera suggest a strong affinity with rutaceous genera, but also could be taken as indicative of an affinity to the Meliaceae genera, where the precursor of the new limonoids $\mathbf{5 7}$ and $\mathbf{5 8}$ occurs, methyl ivorensate (63). The latter and its derivative khayseneganin D (62) were found in Khaya senegalensis. ${ }^{38}$ In addition, several limonoids with carbonate as substituent have been reported from Chukrasia genus of Meliaceae, ${ }^{41}$ and cycloheptanyl ring $\mathrm{C}$ limonoid similar to $\mathbf{6 0}$ occurs in Entandrophragma delevoyi, also Meliaceae. ${ }^{42}$ Thus, the co-occurrence of carbonate substituent and cycloheptanyl ring $\mathrm{C}$ in $\mathrm{S}$. excelsa limonoid $\mathbf{6 0}$, despite having a different skeleton, can also be an indicative of affinity to Meliaceae.

Only one genus, Harrisonia, presently classified in Simaroubaceae, is known to contain limonoids, among which perforatin (53) and harrisonin (54) are also produced by $S$. excelsa. ${ }^{32}$ Limonoids occur mainly in Rutaceae, Meliaceae and Cneoraceae, and quassinoids, biosynthetically related compounds, in Simaroubaceae. ${ }^{34}$ However, quassinoids had remained undiscovered in Harrisonia for many years, but the isolation of perfaraquassin $\mathrm{A}$ in $H$. abyssinica was taken as strong evidence in favor of its retention in the Simaroubaceae. ${ }^{44}$

Prenylated chromones have only been reported from the genera Spathelia, ${ }^{19,23,26,27}$ Sohnreyia, ${ }^{31,32}$ Dictyoloma and Harrisonia, ${ }^{13-15,17,26}$ as well as from the Cneoraceae, and Ptaeroxylaceae. ${ }^{26}$ Chromones have not been found in other Simaroubaceae or Rutaceae. Thus, the co-occurrence of chromones in these taxa is phylogenetically significant by segregating them into a distinct group, according to Appelhans et al. ${ }^{1}$ in Spathelia-Ptaeroxylon clade. ${ }^{1}$

\section{Conclusions}

The new limonoids from Sohnreyia and Dictyoloma show similarities with those from Rutaceae and Meliaceae, providing support for moving Spathelia-Ptaeroxylon clade near to these associated large families. As pointed out above, Sohnreyia and Dictyoloma are well placed in Rutaceae, and then these genera can be regarded as a potential source of coumarins. Thus, it would not be surprising if coumarins had remained undiscovered in both genera because of their low concentration. The most common type of linear furocoumarin, among which xanthyletin is of widespread occurrence, was obtained here from S. excelsa in substantial amounts (7.4 mg), which stimulated undertaking a further investigation of Sohnreyia, Spathelia and Dictyoloma species searching for coumarins.

\section{Supplementary Information}

Supplementary information (NMR spectra) is available free of charge at http://jbcs.sbq.org.br as PDF file.

\section{Acknowledgments}

The authors thank the Brazilian agencies National Council for Scientific and Technological Development (CNPq-INCT, 465357 / 2014-8), São Paulo Research Foundation (FAPESP-INCT, 2014 / 509187; Temático 2012 / 25299-6, APR 2016 / 16117-2), FAPESPGlaxoSmithKline (2014 / 50249-8) and Coordination for the Improvement of Higher Education Personnel (CAPES, 88887.136357 / 2017-00).

\section{References}

1. Appelhans, M. S.; Smets, E.; Razafimandimbison, S. G.; Haevermans, T.; van Marle, E. J.; Couloux, A.; Rabarison, H.; Randrianarivelojosia,M.; Kessler,P.J.A.;Ann. Bot. 2011,107, 1259.

2. Bentham, G.; Hooker, J. D.; Genera Plantarum, vol. 1; L. Reeve: London, 1862.

3. Engler, A. In Flora Brasiliensis, vol. 2; Martius, C. F. P.; Eichler, A. G., eds.; R. Oldenbourg: Munich, 1874, p. 76.

4. Chiovenda E.; Resultati Scientifici della Missione StefaniniPaoli nella Somalia italiana; Tipografia Galletti e Cocci: Firenze, 1916.

5. Engler, A. In Die Natürlichen Pflanzenfamilien, vol. 19a, $2^{\text {nd }}$ ed.; Engler, A.; Prantl, K., eds.; Engelmann: Leipzig, 1931, p. 187.

6. Nooteboom H. P.; In Flora Malesiana, vol. 6; Van Steenis, C. G. G. J., ed.; Wolters-Noordhoff Publishing: Groningen, 1962, series 1, p. 193.

7. Leroy, J. F.; Lescot, M. In Flore de Madagascar et des Comores; Morat, Ph., ed.; Muséum National d'Histoire Naturelle: Paris, 1991, p. 87.

8. Ham, R. W. J. M.; Baas, P.; Bakker, M. E.; Kew Bull. 1995, 50, 243.

9. Krause, K.; Notizbl. Königl. Bot. Gartens Mus. Berlin 1914, $55,143$.

10. Harms, H. In Die Natürlichen Pflanzenfamilien; Engler, A.; Harms, H., eds.; Verlag von Wilhelm Engelmann: Leipzig, 1931, p. 457.

11. Macbride, J. F.; Field Mus. Nat. Hist. Publ., Bot. Ser. 1949, 3, 511.

12. Patcher, I. J.; Zacharias, D. E.; Riberio, O.; J. Org. Chem. 1959, 24, 1285. 
13. Campos, A. M.; Dokhac, D.; Fetizon, M.; Phytochemistry 1987, 26, 2819.

14. Vieira, P. C.; Lázaro, A. R.; Fernandes, J. B.; Silva, M. F. G. F.; Biochem. Syst. Ecol. 1988, 16, 541.

15. Vieira, P. C.; Lázaro; A. R.; Fernandes, J. B.; Silva, M. F. G. F.; Quim. Nova 1990, 13, 287.

16. Sartor, C. F.; Silva, M. F. G. F.; Fernandes, J. B.; Vieira, P. C.; Rodrigues Fo, E.; Cortez, D. A. G.; Phytochemistry 2003, 63, 185.

17. Alves, I. M.; Abreu, L. S.; Costa, C. O. S.; Hyaric, M. L.; Guedes, M. L. S.; Soares, M. B. P.; Bezerra, D. P.; Velozo, E. S.; Chem. Biodiversity 2017, 14, e1600276.

18. Lavaud, C.; Massiot, G.; Vasquez, C.; Moretti, C.; Sauvain, M.; Balderrama, L.; Phytochemistry 1995, 40, 317.

19. Box, V. G.; Taylor, D. R.; Phytochemistry 1973, 12, 956.

20. Harding, W. W.; Lewis, P. A.; Jacobs, H.; McLean, S.; Reynolds, W. F.; Tay, L.-L.; Yang, J.-P.; Tetrahedron Lett. 1995, 36, 9137.

21. Morimoto, Y.; Takaishi, M.; Iwai, T.; Kinoshita, T.; Jacobs, H.; Tetrahedron Lett. 2002, 43, 5849.

22. Tinto, W. F.; McLean, S.; Reynolds, W. F.; Carter, C. A. G.; Tetrahedron Lett. 1993, 34, 1705.

23. Diaz, M.; Preiss, A.; Meyer, H.; Ripperger, H.; Phytochemistry 1983, 22, 2090.

24. Burke, B. A.; Chan, W. R.; Taylor, D. R.; Tetrahedron 1972, 28,425 .

25. Mester, I. In Chemistry and Chemical Taxonomy of the Rutales; Waterman, P. G.; Grundon, M. F., eds.; Academic Press: London, 1983, p. 31.

26. Gray, A. I. In Chemistry and Chemical Taxonomy of the Rutales; Waterman, P. G.; Grundon, M. F., eds.; Academic Press: London, 1983, p. 97.

27. Suwanborirux, K.; Chang, C.-J.; Cassady, J. M; J. Nat. Prod. 1987, 50, 102.

28. Simpson, D. S.; McLean, S.; Reynolds, W. F.; Jacobs, H.; Nat. Prod. Commun. 2010, 5, 859.
29. Lima, M. P.; Rosas, L. V.; Silva, M. F. G. F.; Ferreira, A. G.; Fernandes, J. B.; Vieira, P. C.; Phytochemistry 2005, 66, 1560.

30. Freitas, A. C.; Lima, M. P.; Ferreira, A. G.; Tadei, W. P.; Pinto, A. C. S.; Quim. Nova 2009, 32, 2068.

31. Moreira, W. A. S.; Lima, M. P.; Ferreira, A. G.; Ferreira, I. C. P.; Nakamura, C. V.; J. Braz. Chem. Soc. 2009, 20, 1089.

32. Carvalho, L. E.; Lima, M. P.; Máximo, A. C.; Pereira, E. C. S.; Moreira, W. A. S.; Ferreira, A. G.; Véras, S. M.; Souza, M. G.; Quim. Nova 2012, 35, 2237.

33. Silva, M. F. G. F.; Gottlieb, O. R.; Biochem. Syst. Ecol. 1987, 15,85 .

34. Zhang, Y.; Xu, H.; RSC Adv. 2017, 7, 35191.

35. Dreyer, D. L. In Chemistry and Chemical Taxonomy of the Rutales; Waterman, P. G.; Grundon, M. F., eds.; Academic Press: London, 1983, p. 215.

36. Li, Q.; Huang, X.; Li, S.; Ma, J.; Lv, M.; Xu, H.; J. Agric. Food Chem. 2016, 64, 5472.

37. Epe, B.; Mondon, A.; Tetrahedron Lett. 1979, 22, 2015.

38. Yuan, C.-M.; Zhang, Y.; Tang, G.-H.; Di, Y.-T.; Cao, M.-M.; Wang, X.-Y.; Zuo, G.-Y.; Li, S.-L.; Hua, H.-M.; He, H.-P.; Hao, X.-J.; J. Nat. Prod. 2013, 76, 327.

39. Carey, F. A.; Sundberg, R. J.; Advanced Organic Chemistry. Part A: Structure and Mechanisms, $3^{\text {rd }}$ ed.; Plenum Press: New York, 1990, ch. 11.

40. Agrawal, P. K.; Carbon-13 NMR of Flavonoids; Elsevier: New York, 1989.

41. Zhang, H; Liu, H.-B.; Yue, J.-M.; Chem. Rev. 2014, 114, 883.

42. Mulholland, D. A.; Schwikkard, S. F.; Sandor, P.; Nuzillard, J. M.; Phytochemistry 2000, 53, 465.

43. Biavatti, M. W.; Vieira, P. C.; Silva, M. F. G. F.; Fernandes, J. B.; Albuquerque, S.; Z. Naturforsch. 2001, 56, 570.

44. Rajab, M. S.; Fronczek, F. R.; Mulholland, D. A.; Rugutt, J. K.; Phytochemistry 1999, 52, 127.

Submitted: February 12, 2019

Published online: July 18, 2019 